\title{
Community-acquired pneumonia in Chile: the clinical relevance in the detection of viruses and atypical bacteria
}

\author{
Vivian Luchsinger, ${ }^{1}$ Mauricio Ruiz, ${ }^{2}$ Enna Zunino, ${ }^{3}$ María Angélica Martínez, ${ }^{4}$ \\ Clarisse Machado, ${ }^{5}$ Pedro A Piedra, ${ }^{6}$ Rodrigo Fasce, ${ }^{7}$ María Teresa Ulloa, ${ }^{4}$ \\ Maria Cristina Fink, ${ }^{5}$ Pamela Lara, ${ }^{1}$ Mónica Gebauer, ${ }^{3}$ Fernando Chávez, ${ }^{3}$ \\ Luis F Avendaño ${ }^{1}$
}

\begin{abstract}
${ }^{1}$ Programa de Virología, Facultad de Medicina, Universidad de Chile, Santiago, Chile

${ }^{2}$ Facultad de Medicina, Hospital Clínico Universidad de Chile, Santiago, Chile ${ }^{3}$ Facultad de Medicina, Hospital de Infecciosos Dr. Lucio Córdova, Santiago, Chile

${ }^{4}$ Programa de Microbiología, Facultad de Medicina Universidad de Chile, Santiago, Chile

${ }^{5}$ Laboratorio de Virología, Instituto de Medicina Tropical de São Paulo, Universidade de São Paulo, São Paulo, Brazi ${ }^{6}$ Department of Molecular Virology and Microbiology, and Pediatrics, Baylor College of Medicine, Houston, Texas, USA ${ }^{7}$ Sección Virus Respiratorios y Exantemáticos, Subdepartamento Enfermedades Virales, Instituto de Salud Pública de Chile, Santiago, Chile
\end{abstract}

\section{Correspondence to} Luis F Avendaño, Programa de Virología, Facultad de Medicina, Universidad de Chile, Av. Independencia 1027, Independencia, Santiago 8380453, Chile;

lavendan@med.uchile.cl

Presented in part: Poster in XXXIII Congreso Chileno de Microbiología, Olmué, Chile, November 2011.

Received 11 March 2013 Revised 19 April 2013 Accepted 21 May 2013 Published Online First 19 June 2013

To cite: Luchsinger $\mathrm{V}$ Ruiz M, Zunino E, et al. Thorax 2013;68:

1000-1006.

\section{ABSTRACT}

Background Adult community-acquired pneumonia (CAP) is a relevant worldwide cause of morbidity and mortality, however the aetiology often remains uncertain and the therapy is empirical. We applied conventional and molecular diagnostics to identify viruses and atypical bacteria associated with CAP in Chile.

Methods We used sputum and blood cultures, IgG/lgM serology and molecular diagnostic techniques (PCR, reverse transcriptase PCR) for detection of classical and atypical bacteria (Mycoplasma pneumoniae, Chlamydia pneumoniae, Legionella pneumoniae) and respiratory viruses (adenovirus, respiratory syncytial virus (RSV), human metapneumovirus, influenza virus, parainfluenzavirus, rhinovirus, coronavirus) in adults $>18$ years old presenting with CAP in Santiago from February 2005 to September 2007. Severity was qualified at admission by Fine's pneumonia severity index.

Results Overall detection in 356 enrolled adults were $92(26 \%)$ cases of a single bacterial pathogen, 80 $(22 \%)$ cases of a single viral pathogen, $60(17 \%)$ cases with mixed bacterial and viral infection and $124(35 \%)$ cases with no identified pathogen. Streptococcus pneumoniae and RSV were the most common bacterial and viral pathogens identified. Infectious agent detection by PCR provided greater sensitivity than conventional techniques. To our surprise, no relationship was observed between clinical severity and sole or coinfections.

Conclusions The use of molecular diagnostics expanded the detection of viruses and atypical bacteria in adults with CAP, as unique or coinfections. Clinical severity and outcome were independent of the aetiological agents detected.

\section{INTRODUCTION}

Community-acquired pneumonia (CAP) is a worldwide cause of morbidity and mortality. ${ }^{1-3}$ In spite of the advances in diagnostics, the aetiology of CAP often remains uncertain and therapy is empirical. ${ }^{4}$ The low sensitivity of blood and sputum cultures and the presence of a heterogeneous bacterial flora in the upper respiratory tract confound the interpretation of the tests. ${ }^{6}$ Respiratory viruses are the worldwide cause of acute lower respiratory tract infections (ALRIs) in children and their
Key messages

\section{What is the key question?}

- Viruses and atypical bacteria were frequently detected as single and mixed agents in adults with community-acquired pneumonia (CAP).

What is the bottom line?

- Although agent detection increased notably by PCR diagnosis, clinical severity and outcome were independent of the pathogenic agents detected.

Why read on?

- Although adult CAP is a relevant worldwide cause of morbidity and mortality, the aetiology often remains uncertain and the therapy is empirical.

specific diagnosis is often made by immunodiagnostic techniques. In children, unlike in adults, an aetiological diagnosis is easily assessed by many diagnostic techniques because viral shedding is high and prolonged. ${ }^{7} 8$ The development of molecular methods with improved sensitivity and specificity has paved the way for the detection of new viruses, for the identification of pathogens that are difficult to culture, and for the detection of pathogens later in the disease process. Molecular diagnostics have improved our understanding of ALRIs in children and in adults. ${ }^{9-12}$ Seasonality of ALRIs is similar in paediatric and adult respiratory illnesses, suggesting a similar aetiology. In prior reports we presented the epidemiology and clinical impact of Mycoplasma pneumoniae and respiratory syncytial virus (RSV) in Chilean adults with CAP. ${ }^{13-15}$ Here we present a comprehensive evaluation of the bacterial and viral aetiology of CAP in adults. We postulate that viruses and atypical bacteria either as sole or coinfections play a relevant role in adult CAP and that molecular diagnostics will define the specific aetiology in a majority of cases. We also explore the relationship between respiratory pathogen and clinical severity with a validated severity score index. ${ }^{16}$ 


\section{METHODS}

\section{Patients and study design}

A prospective study was conducted in patients $\geq 18$ years of age presenting with CAP in two hospitals in Santiago, Chile from February 2005 to December 2007. The study was approved by the University of Chile and Health Institutional Ethics Committee and all subjects at enrolment gave written informed consent. CAP was defined by the presence of acute respiratory symptoms for less than 1 week and chest radiography showing new pulmonary infiltrates. Exclusion criteria included immunocompromising conditions (ie, HIV, active treatment for cancer, organ transplant, immunosuppressive therapy) and hospitalisations within 30 days preceding enrolment. Information on age, gender, smoking status, prior antibiotic treatment, comorbidities and clinical presentation, vital signs, laboratory parameters, antimicrobial therapy and hospital course were recorded for all patients in standardised files. Chest radiographic patterns were described by independent radiologists as alveolar, interstitial or mixed infiltrates; the extension was categorised according to the number of lobes involved and the presence of pleural effusion. Patient severity was assessed during the first $48 \mathrm{~h}$ after enrolment by the pneumonia severity index described by Fine. ${ }^{16}$ The illness outcome and the presence of complications like renal failure, shock, mechanical ventilation and others were recorded. Patients who died between admission and 30 days after discharge were recorded.

\section{Sample collection}

In addition to routine laboratory tests, such as complete blood cell count, biochemistry panel, oxygen saturation at admission, patients had collection of urine and blood for bacterial culture and acute serum sample for serology. Induced sputum and nasopharyngeal aspirate were obtained and immediately transported on ice to the laboratory for bacterial and viral diagnostics. Aliquots were prepared and stored at $-80^{\circ} \mathrm{C}$ for later testing. Participants were contacted at 4-6 weeks for follow-up and collection of convalescent sera. Serum samples were processed immediately and stored at $-20^{\circ} \mathrm{C}$ until tested.

\section{Viral study}

\section{Specimen processing}

Sample aliquots of respiratory secretions were prepared for immunofluorescent assay, viral isolation in cell culture and real time PCR.

\section{Viral isolation}

Each specimen was processed as previously described. ${ }^{10}$ Briefly, samples were inoculated onto HEp-2 and Madin-Darby canine kidney (MDCK) cell cultures and observed for development of cytopathic effect (CPE) for 1 week, after which confirmatory immunofluorescence assays (IFAs) for RSV, adenovirus, influenza and parainfluenza viruses were performed in both cell cultures with and without CPE.

\section{Indirect immunofluorescence assay}

Smears were prepared in triplicate and IFA was performed for RSV, adenovirus, influenza A and B, parainfluenza virus $1-3$ as described elsewhere, using monoclonal antibodies kindly provided by $\mathrm{L}$ Anderson (CDC, Atlanta) and P Pothier (Dijon, France). We used commercial conjugate (Sigma) and virusspecific monoclonal antibodies (Chemicon) for influenza and parainfluenza virus typing. ${ }^{78}$
Serology

Serum haemagglutination inhibition (HI) test for antibodies to influenza (H3N2, H1N1 and B) was performed as described elsewhere. ${ }^{17}$ Paired sera were inactivated with receptordestroying enzyme ( Denka Seiken Corporation, Tokyo, Japan), incubated overnight at $37^{\circ} \mathrm{C}$, and heated at $56^{\circ} \mathrm{C}$ for $30 \mathrm{~min}$. A $0.5 \%$ turkey red blood cell suspension, control antigens and reference antisera were used. Cases displaying at least a fourfold rise between the acute and convalescent sera were recorded as acute infection.

Sera were tested for antibodies to RSV and human metapneumovirus (hMPV) by microneutralisation assays to RSV/A/Tracy (A2 like virus) and RSV/B/18537 (prototype B virus) to measure RSV/A and RSV/B specific neutralising antibodies as previously described. ${ }^{18}$ hMPV antibodies were also detected by ELISA assays. ${ }^{19}$ Seroconversion was defined by at least a fourfold rise of antibody titre between acute and convalescent sera by one or more of the serological tests.

\section{Reverse transcriptase PCR for RSV and hMPV}

Samples were treated with guanidinium thiocyanate-phenolchloroform method for RNA extraction. ${ }^{20} \mathrm{cDNA}$ was synthesised with $5 \mu \mathrm{L}$ RNA (sample) and $0.52 \mu \mathrm{M} \mathrm{F}$ gene primer (F844: $5^{\prime}$-TGTCTAACTATTTGAACA- $3^{\prime}$ ) for RSV and $10 \mu \mathrm{L}$ RNA and $0.52 \mu \mathrm{M}$ random hexamer primer (Amersham Bioscience) for hMPV, during $1 \mathrm{~h}$ at $37^{\circ} \mathrm{C}$, followed by $5 \mathrm{~min}$ at $95^{\circ} \mathrm{C}$ in a AmpPCR System 2400. For RSV, a sequence of the $\mathrm{N}$ gene was amplified with $10 \mu \mathrm{M}$ (each) of N1 and N2 primers, ${ }^{21} 1 \times$ Master SYBR Green I (Roche) and $2 \mu \mathrm{L}$ of cDNA. For hMPV, a sequence of the $\mathrm{N}$ gene were amplified with $0.5 \mu \mathrm{M}$ (each) of $\mathrm{N} 2$ and $\mathrm{N} 3$ primers. $^{22}$ Cycling conditions included a denaturation step of $10 \mathrm{~min}$ at $94^{\circ} \mathrm{C}$, followed by 50 (RSV) or 40 cycles (hMPV) of $10 \mathrm{~s}$ at $94^{\circ} \mathrm{C}, 5 \mathrm{~s}$ at $58^{\circ} \mathrm{C}(\mathrm{RSV})$ or $52^{\circ} \mathrm{C}(\mathrm{hMPV}), 30 \mathrm{~s}$ at $72^{\circ} \mathrm{C}$ in a Light Cycler 1.5 instrument (Roche). Amplicons were analysed by melting curve analysis. Appropriated controls were included in each assay.

Reverse transcriptase PCR for rhinovirus and coronavirus detection Human coronavirus (HCoV), and picornavirus (PV) were detected by real time reverse transcriptase PCR (RT-PCR) by amplifying the conserved region of the replicase $1 \mathrm{a}$ gene and the $5^{\prime} \mathrm{NCR}$ conserved region, respectively, as previously described. $^{23} 24$ The $390 \mathrm{bp}$ fragment of PV was purified and sequenced using the kit ABI PRISM Dye Terminator Cycle Sequencing ready Reaction in the automated sequencer ABI model 377 (Applied Biosystems, Inc, USA). Sequences were aligned to other sequences in the Gene Bank using the programme Blast to differentiate between rhinovirus and enterovirus.

\section{Bacterial study}

Cultures

Sputum samples displaying $>25$ leukocytes and $<10$ epithelial cells per $100 \times$ power field after Gram staining were cultured and processed according to standard techniques. ${ }^{6} 25$ Urinary antigens for Streptococcus pneumoniae were detected using immunochromatographic tests (Binax NOW, Portland, Oregon, USA). ${ }^{26}$ For Legionella species isolation, a subset of 256 samples were inoculated onto BCYE and GVPC media (Oxoid) and incubated at $37.8^{\circ} \mathrm{C}$ for up to 10 days; 125 of these cases were also studied for urinary antigen using immunochromatographic tests. ${ }^{27}$ Confirmatory PCR was performed on positive samples as described elsewhere. ${ }^{28}$ 


\section{Polymerase chain reaction}

Chlamydophila pneumoniae was detected using a nested PCR directed to a chromosomal DNA segment (PstI 474) using the reference strains AR-39, TW-183 and CM-1 as positive controls. Primers HL and HR were used for the first PCR and nested PCR was performed as described elsewhere. ${ }^{29}{ }^{30}$ For $M$ pneumoniae a PCR directed to a $277 \mathrm{bp}$ fragment of the $16 \mathrm{~S}$ rRNA gene was used, including a $\mathrm{M}$ pneumoniae $\mathrm{FH}$ strain as positive control. $^{1431}$

\section{Serology}

Serum samples were tested for IgM and IgG antibodies by indirect IFA using commercial kits. Sera were absorbed with an antihuman IgG reagent (Zorba, Zeus, Inc, USA) prior to IgM testing. The Chlamydia kit (SeroFIA, Sayvon, Israel) was used for $C$ pneumoniae and $\operatorname{IgM} \geq 1: 16$ or a fourfold rise in $\operatorname{IgG}$ titres between paired sera were regarded as acute infection; single or standing $\operatorname{IgG}$ titres $\geq 1: 512$ were considered as past infections. For M pneumoniae another IFA test was used (Zeus, USA) and acute infection was assigned with $\operatorname{IgM} \geq 1: 32$ or seroconversion in paired sera. ${ }^{32}$ Sera determinations were done blindly with respect to other viral or bacterial tests.

\section{Statistical analysis}

Analysis was performed using the Z-test for categorical data and the $t$ test, Mann-Whitney rank sum or Kruskal-Wallis one-way analysis of variance for continuous variables. The level of significance was set at $\mathrm{p}<0.05$. Data were analysed using SigmaStat software.

\section{RESULTS}

\section{Patients and samples}

Respiratory secretions and urine were obtained from 356 patients from 330 hospitalised and 26 ambulatory cases. Good-quality sputum samples were available for 233 (65\%) cases. Blood culture was performed in 241 (75\%) patients and paired sera were available for $211(68 \%)$ patients. Rhinovirus and coronavirus were studied in a subset of 268 cases from August 2005 to September 2007. Serology for influenza was performed only in cases with paired sera, which covered the three annual seasonal influenza epidemics. A respiratory pathogen was detected in 232 (65.2\%) of 356 cases, corresponding to bacteria in $92(26 \%)$ and viruses in $80(22 \%)$ cases. Mixed viral/bacterial infections were detected in $60(17 \%)$ cases. In $124(35 \%)$ patients no agent was detected (table 1). Death occurred in $28(7.8 \%)$ cases, without significant difference between those with or without a detected infectious agent.

Table 1 Distribution of 356 adults with community-acquired pneumonia by infection classification

\begin{tabular}{lrc}
\hline Infection classification & N & $\%$ \\
\hline Negative cases & 124 & 34.8 \\
Only bacteria* & 92 & 25.8 \\
Only viruses* & 80 & 22.5 \\
Mixedt & 60 & 16.9 \\
\hline Santiago, Chile, February 2005-December 2007. & \\
*One or more agents per case. & \\
tMixed virus and bacteria, with one or more agents per case. &
\end{tabular}

\section{Clinical characteristics of population}

Demographic risk factors, comorbidities and outcomes were not significantly different between those with or without a detectable pathogen (table 2). Also laboratory parameters like haemogram, glucose, electrolytes, urea and liver function enzymes did not exhibit significant differences (data not showed). Only C-reactive protein was significantly higher in patients with a detectable pathogen (median $=211 \mathrm{mg} / \mathrm{dL}$ ) compared with patients without an identifiable pathogen (median $=158 \mathrm{mg} / \mathrm{dL}$ ) $(\mathrm{p}=0.01)$, although with a broad range in values (table 2$)$.

The clinical outcome related to the presence of complications, like radiologic progression, respiratory failure, need for mechanical ventilation or presence of shock, failed to show any significant difference between both groups. Only liver damage $(14 / 221=6.3 \%$ vs $1 / 119=0.8 \% ; p=0.03)$ was significantly

Table 2 General characteristics of 356 patients with community-acquired pneumonia, according to detection of an infectious agent

\begin{tabular}{|c|c|c|c|}
\hline Characteristic & With agent & Without agent & $\begin{array}{l}p \\
\text { Value* }\end{array}$ \\
\hline $\mathrm{N}$ & 232 & 124 & \\
\hline Age (years), median (range) & $61(18-94)$ & 66 (18-93) & 0.1 \\
\hline Men, n (\%) & $128(55.2)$ & $63(50.8)$ & 0.4 \\
\hline Death, $n(\%)$ & $17(7.3)$ & $11(8.9)$ & 0.6 \\
\hline $\begin{array}{l}\text { Hospital stay (days), median/ } \\
\text { n (range) }\end{array}$ & 7/190 (1-71) & 7/104 (1-82) & 0.3 \\
\hline Hospitalisation, n (\%) & $211(90.9)$ & $119(96.0)$ & 0.1 \\
\hline ICU admission, n (\%) & $53(22.8)$ & $30(24.2)$ & 0.7 \\
\hline Outpatients, n (\%) & $21(9.1)$ & $5(4.0)$ & 0.1 \\
\hline Smokers, n (\%) & $90 / 220(40.1)$ & $37 / 119(31.1)$ & 0.1 \\
\hline $\begin{array}{l}\text { Alcohol use }>80 \text { g/day, n/N } \\
(\%)\end{array}$ & $31 / 221(14)$ & $11 / 119(9.2)$ & 0.2 \\
\hline Comorbidity, n (\%) & $\mathrm{N}=221$ & $\mathrm{~N}=119$ & \\
\hline Any & $112(50.7)$ & $66(55.5)$ & 0.4 \\
\hline Diabetes mellitus & $36(16.3)$ & $19(15.9)$ & 0.9 \\
\hline COPD & $36(16.3)$ & $23(19.3)$ & 0.5 \\
\hline Asthma & $12(5.4)$ & $4(3.4)$ & 0.5 \\
\hline Cardiac failure & $38(17.2)$ & $23(19.3)$ & 0.7 \\
\hline Liver damage & $14(6.3)$ & $1(0.8)$ & 0.03 \\
\hline Renal disease & $4(1.8)$ & $7(5.9)$ & 0.08 \\
\hline $\begin{array}{l}\text { Antibiotics prior to } \\
\text { admission, } \mathrm{n} / \mathrm{N}(\%)\end{array}$ & 48/220 (21.8) & $24 / 119(20.2)$ & 0.8 \\
\hline Mental confusion, n/N (\%) & $55 / 219(25.1)$ & 22/115 (19.1) & 0.2 \\
\hline Hypotension, n/N (\%) & $36 / 218(16.5)$ & 26/119 (21.9) & 0.2 \\
\hline Shock, n/N (\%) & 21/217 (9.7) & 9/119 (7.6) & 0.6 \\
\hline $\begin{array}{l}\text { Respiratory rate, median } / n \\
\text { (range) }\end{array}$ & 24/172 (18-48) & 24/99 (15-46) & 0.8 \\
\hline Pulse, median/n (range) & $95 / 214(17-153)$ & $91 / 119(10-180)$ & 0.1 \\
\hline $\begin{array}{l}\text { Systolic blood pressure } \\
(\mathrm{mm} \mathrm{Hg}), \text { median/n (range) }\end{array}$ & 120/178 (68-213) & 123/178 (70-195) & 0.6 \\
\hline $\begin{array}{l}\text { Temperature at admission }\left(^{\circ}\right. \\
\text { C), median/n (range) }\end{array}$ & $37.2 / 219(35-41)$ & $37.4 / 117(35-40.5)$ & 0.9 \\
\hline $\begin{array}{l}\text { C-reactive protein }(\mathrm{mg} / \mathrm{dL}) \text {, } \\
\text { median/n (range) }\end{array}$ & $211 / 182(2-569)$ & 158/101 (3-454) & 0.02 \\
\hline Chest radiograph, n (\%) & $\mathrm{N}=217$ & $\mathrm{~N}=115$ & \\
\hline Interstitial patterns & $31(14.3)$ & $12(10.4)$ & 0.4 \\
\hline Alveolar patterns & $173(79.7)$ & $95(83.3)$ & 0.5 \\
\hline Both & $13(5.9)$ & $8(6.9)$ & 0.9 \\
\hline Multilobar involvement & 70 (32.6) & $42 / 113(37.2)$ & 0.4 \\
\hline
\end{tabular}


higher in patients with a detectable pathogen (table 2). However, clinical severity of cases correlated with parameters classically described, like age, comorbidity, hypotension, hepatic failure and others (table 3).

\section{Viral and bacterial agent detection}

The most commonly identified bacteria was $S$ pneumoniae $(75=21.1 \%)$, although it was the sole pathogen in 38 cases (table 4). Of these 75 patients, 39 were tested by sputum culture, 61 by blood culture and 73 by urine antigen detection, and $S$ pneumoniae was identified in 12 (30.8\%), 15 (24.6\%) and $60(82.2 \%)$ cases, respectively.

M pneumoniae and C pneumoniae were detected in 32 (9\%) and $28(7.9 \%)$ cases, respectively, but only in 13 cases for each agent were they the sole pathogen. For M pneumonia, PCR and serology yielded similar results $(69.7 \%$ and $72.7 \%$, respectively; $42.4 \%$ of cases were positive by both tests). C pneumoniae was detected by PCR $(19 / 28)$ and serology $(15 / 28)$, with 6 of 28 cases $(21.4 \%)$ detected by both tests. Legionella pneumophila was detected in $13 / 256$ cases $(5.07 \%), 3$ by culture, 10 by antigen detection (one by both); all cases were confirmed by PCR. The most commonly detected viruses were RSV $(n=48)$, PV $(n=41)$ and hMPV $(n=41)$, but single infections occurred in only 18,17 and 8 cases, respectively (table 4).

\section{Yield of different techniques for viral diagnosis}

Detection of a viral pathogen by conventional IFA and cell culture techniques was infrequent, with only 2 of 48 RSV infections and 6 of 27 influenza cases. The RT-PCR technique identified 32 RSV cases. The microneutralisation serology for RSV and $\mathrm{HI}$ for influenza detected seroconversion in 20 of 184 $(10.8 \%)$ and 26 of $211(12.8 \%)$ adults with paired sera, respectively. RT-PCR was the only test applied for hMPV, PV and coronavirus diagnosis, resulting in the detection of 41 (11.5\%), 41 $(11.5 \%)$ and $20(4.5 \%)$ cases, respectively (table 4$)$.

Table 3 Clinical characteristics of 330 patients with community-acquired pneumonia admitted to ICUs or general wards

\begin{tabular}{|c|c|c|c|}
\hline Clinical parameters & ICU & General Wards & $p$ Value* \\
\hline $\mathrm{N}$ & 83 & 247 & \\
\hline Age (years), median (range) & $68(20-93)$ & $63(18-94)$ & 0.06 \\
\hline Men, n (\%) & $39(47.0)$ & $138(55.9)$ & 0.2 \\
\hline Hospital stay (days), median/n (range) & $116 / 80(24-196)$ & $6 / 195(1-61)$ & $<0.001$ \\
\hline Comorbidity, n (\%) & $\mathrm{N}=81$ & $\mathrm{~N}=233$ & \\
\hline Any & $56(69.1)$ & $118(50.6)$ & 0.006 \\
\hline Diabetes mellitus & $19(23.5)$ & $66(28.3)$ & 0.4 \\
\hline Chronic obstructive pulmonary dis. & $14(17.3)$ & $76(32.6)$ & 0.01 \\
\hline Asthma & $1(1.2)$ & $26(11.2)$ & 0.01 \\
\hline Cardiac failure & $22(27.2)$ & $55(23.6)$ & 0.6 \\
\hline Liver damage & $7(8.7)$ & $13(5.6)$ & 0.7 \\
\hline Renal disease & $5(6.2)$ & $8(3.4)$ & 0.7 \\
\hline Antibiotics prior to admission, $\mathrm{n} / \mathrm{N}(\%)$ & $17 / 82(20.7)$ & $47 / 233(20.2)$ & 0.9 \\
\hline \multicolumn{4}{|l|}{ Infectious agent detected, $\mathrm{n}(\%)$} \\
\hline Virus & $17(20.5)$ & $58(23.5)$ & 0.6 \\
\hline Bacteria & $19(22.9)$ & $63(25.5)$ & 0.7 \\
\hline Virus-bacteria coinfection & $17(20.5)$ & $37(14.9)$ & 0.3 \\
\hline Negative & $30(36.1)$ & $89(36.0)$ & 0.9 \\
\hline Mental confusion, $\mathrm{n} / \mathrm{N}(\%)$ & $45 / 82(54.9)$ & $32 / 230(13.9)$ & $<0.001$ \\
\hline Pleural effusion, $\mathrm{n} / \mathrm{N}(\%)$ & 25/81 (30.9) & $37 / 228(16.2)$ & 0.008 \\
\hline Hypotension, n/N (\%) & $40 / 80(50.0)$ & $19 / 231(8.2)$ & $<0.001$ \\
\hline Respiratory rate, median/n (range) & $28 / 79(18-36)$ & $24 / 168(16-40)$ & $<0.001$ \\
\hline Pulse, median/n (range) & $105 / 81(73-142)$ & $93 / 226(41-180)$ & $<0.001$ \\
\hline Systolic pressure (mm Hg), median/n (range) & $110 / 79(68-213)$ & $122 / 174(75-195)$ & 0.006 \\
\hline Diastolic pressure (mm Hg), median/n (range) & $60 / 78(26-133)$ & 70/174 (43-97) & $<0.001$ \\
\hline Chest Rx multilobar involvement, $\mathrm{n} / \mathrm{N}(\%)$ & $41 / 81(50.6)$ & $65 / 229(28.9)$ & $<0.001$ \\
\hline Fine score, $\mathrm{n}(\%)$ & $\mathrm{N}=83$ & $\mathrm{~N}=247$ & \\
\hline 1 & $5(6.0)$ & $64(25.9)$ & $<0.001$ \\
\hline 2 & $6(7.2)$ & $59(23.9)$ & $<0.001$ \\
\hline 3 & $15(18.1)$ & $53(21.5)$ & 0.6 \\
\hline 4 & $24(28.9)$ & $62(25.1)$ & 0.6 \\
\hline 5 & $33(39.8)$ & $9(3.6)$ & $<0.001$ \\
\hline Blood urea (mg/dL), median/n (range) & $21 / 79(8-116)$ & $18 / 219(6-75)$ & $<0.001$ \\
\hline Chest Rx progression, $\mathrm{n} / \mathrm{N}(\%)$ & $13 / 80(16.3)$ & $7 / 231(3.0)$ & $<0.001$ \\
\hline Hepatic failure, n/N (\%) & $8 / 80(10.0)$ & $1 / 231(0.4)$ & $<0.001$ \\
\hline Respiratory failure, n/N (\%) & $29 / 80(36.3)$ & 24/232 (10.3) & $<0.001$ \\
\hline Shock, n/N (\%) & $27 / 80(33.8)$ & $3 / 231(1.3)$ & $<0.001$ \\
\hline Death during hospitalisation and until 30 days post discharge, $\mathrm{n} / \mathrm{N}(\%)$ & $17 / 83(20.5)$ & 9/247 (3.6) & $<0.001$ \\
\hline
\end{tabular}


Table 4 Distribution of single and multiple viral and bacterial agents detected in 356 adults with community-acquired pneumonia

\begin{tabular}{|c|c|c|c|c|c|c|}
\hline \multicolumn{7}{|l|}{ Bacterial agents } \\
\hline & \multicolumn{2}{|c|}{ Only bacteria ( $n=92)$} & \multicolumn{4}{|c|}{ Mixed bacterial and viral infections $(n=60)$} \\
\hline & \multirow[b]{2}{*}{ Only one } & \multirow[b]{2}{*}{ Plus other bacteria } & \multirow[b]{2}{*}{ Plus virus } & \multirow[b]{2}{*}{ Plus virus and other bacteria } & \multicolumn{2}{|l|}{ Total } \\
\hline & & & & & $\mathrm{N}$ & $\%$ \\
\hline Streptococcus pneumoniae & 38 & 6 & 25 & 6 & 75 & 21.1 \\
\hline Haemophilus influenzae & 3 & & & & 3 & 0.8 \\
\hline Moraxella catarrhalis & 1 & 3 & 2 & & 6 & 1.7 \\
\hline Gram(-)bacillus & 1 & 2 & & 2 & 5 & 1.4 \\
\hline Staphylococcus aureus & 3 & 1 & 2 & 2 & 8 & 2.2 \\
\hline Streptococcus agalactiae & & & 1 & & 1 & 0.3 \\
\hline Mycoplasma pneumoniae & 13 & 5 & 13 & 1 & 32 & 9.0 \\
\hline Chlamydia pneumoniae & 13 & 5 & 4 & 6 & 28 & 7.9 \\
\hline Legionella pneumophila & 7 & 2 & 4 & & 13 & $5.07^{*}$ \\
\hline Subtotal cases with bacteria & 80 & & & & $152 \dagger$ & 42.7 \\
\hline
\end{tabular}

Viral agents

\begin{tabular}{|c|c|c|c|c|c|c|}
\hline & \multicolumn{2}{|c|}{ Only viruses $(n=80)$} & \multicolumn{4}{|c|}{ Mixed viral and bacterial infections $(n=60)$} \\
\hline & \multirow[b]{2}{*}{ Only one } & \multirow[b]{2}{*}{ Plus other virus } & \multirow[b]{2}{*}{ Plus bacteria } & \multirow[b]{2}{*}{ Plus bacteria and other virus } & \multicolumn{2}{|l|}{ Total } \\
\hline & & & & & $\mathbf{N}$ & $\%$ \\
\hline RSV & 18 & 8 & 12 & 10 & 48 & 13.5 \\
\hline hMPV & 8 & 14 & 10 & 9 & 41 & 11.5 \\
\hline Flu & 12 & 5 & 7 & 3 & 27 & 7.6 \\
\hline $\mathrm{HCoV}$ & 3 & 9 & 3 & 5 & 20 & 5.6 \\
\hline Picornavirus & 17 & 11 & 9 & 4 & 41 & 11.5 \\
\hline ADV & 1 & & 2 & & 3 & 0.8 \\
\hline Subtotal cases with viruses & 59 & & & & $140 \ddagger$ & 39.3 \\
\hline No agent & & & & & 124 & 34.8 \\
\hline
\end{tabular}

\section{Seasonality}

During the 36-month survey, respiratory viruses were circulating with clear predominance of RSV during the three winter seasons (May-July) (figure 1); influenza viruses presented as an epidemic in autumn/winter and parainfluenza viruses had higher prevalence during the autumn months. This epidemiology is consistent with the patterns previously reported in Chile. ${ }^{10}$ CAP peaked during the winter months. It was influenced by the epidemiology observed with $S$ pneumoniae, RSV and influenza virus. Other agents were endemic throughout the year (figure 1).

\section{Clinical severity and infection classification}

The analysis of demographic and clinical parameters failed to demonstrate a relationship between infection classification (bacteria, virus or mixed coinfection) and illness severity outcome. Furthermore, the presence of multiple pathogens did not contribute to more severe disease (data not shown). Fine's severity score applied at admission also did not display differences among the pathogenic groupings (table 5).

\section{DISCUSSION}

The aetiology of CAP in adults is not well understood. We undertook this prospective study over a 3-year period in Santiago to determine if comprehensive use of conventional and molecular diagnostics would improve the aetiological identification of adult CAP and to determine if the aetiological agent impacted disease severity. An aetiological agent was identified in $65 \%$ of cases. $S$ pneumoniae and RSV were the most common bacterial and viral pathogens identified. Single and coinfections occurred in 139 (39\%) and 93 (26\%) CAP cases, respectively. Potentially vaccine-preventable pathogens (S pneumonia and influenza virus) were involved in $102(28.7 \%)$ of the 356 CAP cases. The analysis was done globally, comparing groups with and without a detectable infectious agent and by infection classification (viral, bacterial and mixed viral and bacterial) because sole infection by a few major pathogens was uncommon.

Adult CAP was observed year round, with distinct winter seasonality. Outbreaks of $S$ pneumoniae, RSV and influenza contributed to the increase in adult CAP during the winter months. Effective vaccines are available against influenza and $S$ pneumoniae. Increased use of these vaccines could reduce the rates of adult CAP, in particular during the winter months. In this study information on vaccination history was not recorded. Historically vaccination against influenza and $S$ pneumoniae in adults has not been well accepted by this population, even though there are existing national recommendations for vaccinating older adults and at-risk groups.

Comprehensive use of molecular diagnostics, serological assays, urinary antigen tests, and induced sputum and blood 

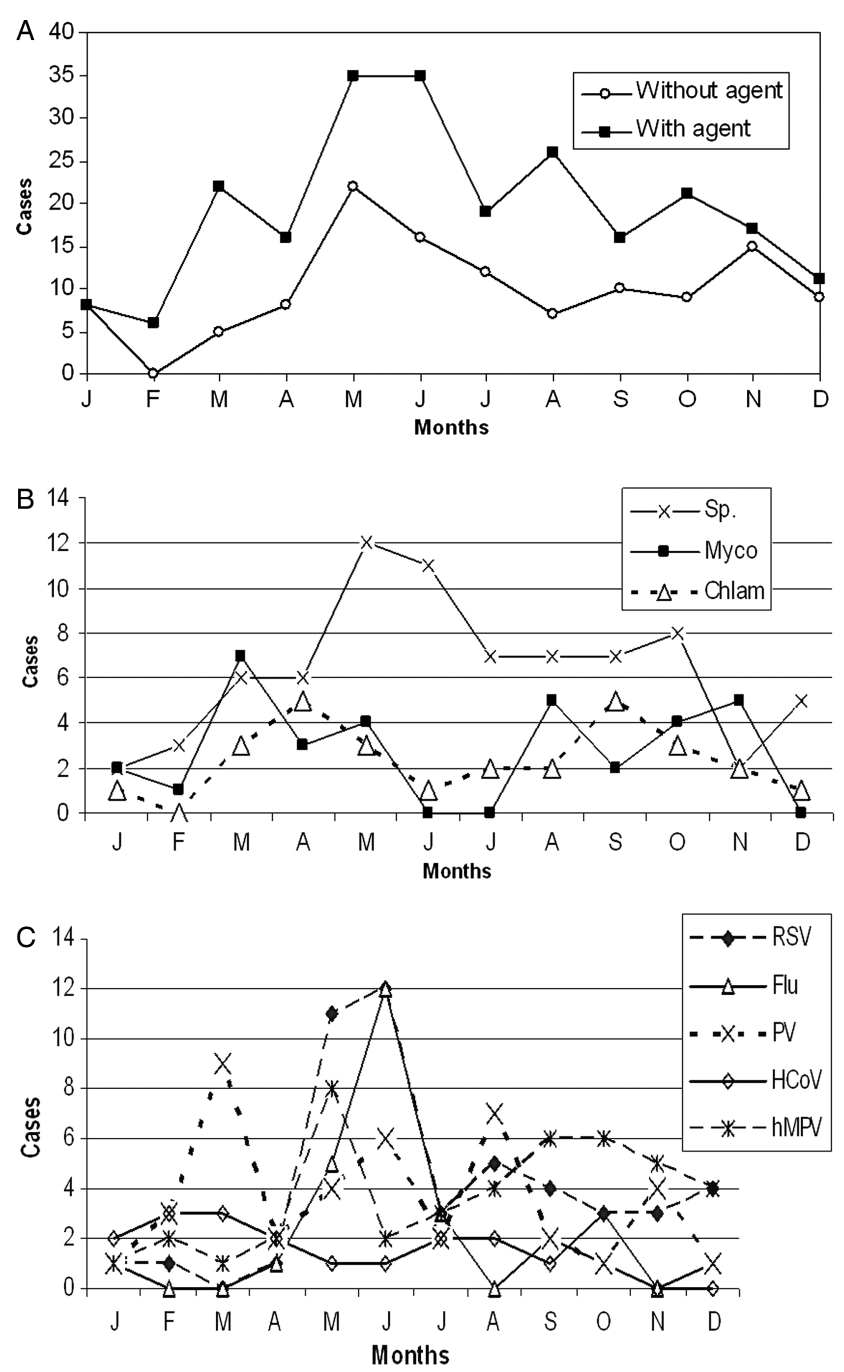

Figure 1 Monthly distribution of 356 adults presenting with community-acquired pneumonia, according to infectious agent identified in Santiago, Chile, February 2005 to December 2007. (A) Cases with and without a detectable infectious agent. (B) Cases associated with a bacterial pathogen (Streptococcus pneumonia (Sp), Mycoplasma Pneumonia (Myco), Chlamydia pneumonia (Chlam). (C) Cases associated with a viral pathogen ( respiratory syncytial virus (RSV), influenza (Flu), picornavirus (PV), coronavirus (HCoV), metapneumovirus (hMPV)).

cultures improved the overall detection of an infectious agent in adults presenting with CAP. Viral and the atypical bacteria detection were as frequent as the classical $S$ pneumoniae. There were no antecedent symptoms or signs that could be associated with one specific aetiological agent. In addition, chest radiograph findings could not define the aetiology.

The identification of a bacterial agent using sputum and blood cultures was infrequent, and the detection of a bacterial pathogen was improved with the use of the urinary antigen assay for $S$ pneumoniae. The implementation of molecular diagnostic technology has enhanced and broadened the spectrum of potential aetiological agents because of the improved identification of known agents and the recognition of new agents associated with respiratory illnesses. ${ }^{33} 34$ In virology, molecular techniques are extensively used and for some agents they constitute the principal method for identification (ie, hMPV, PV, coronavirus). Furthermore, the diminished load and shorter duration of viral shedding that occurs in adults compared with children makes the use of highly sensitive diagnostic tools necessary in adults. For atypical bacteria, PCR should be used as the primary diagnostic technique; unfortunately, its application is often restricted to major academic and diagnostic centres.

To our surprise, we were unable to find a relationship between illness severity and major pathogenic grouping or infection classification. Most of the agents detected occurred more frequently with other pathogens than as the sole pathogen. We detected many infectious agents using new diagnostic technology, but the translation of this finding was not clear. The detection of traditional pathogens, like $S$ pneumoniae and atypical bacteria, could explain the clinical outcome, but the detection of RSV and hMPV, recognised viral respiratory pathogens in the paediatric population, must be carefully considered in adults. The identification of other viruses such as rhinoviruses and coronaviruses makes it more difficult to assign an aetiological interpretation because asymptomatic infections and prolonged viral shedding can also occur. The frequent detection of two or more infectious agents could be the more likely situation in CAP compared with the classical assignation of a single agent to a pathogenic outcome. ${ }^{34}$ Clinical or radiological features are not characteristic of $S$ pneumoniae CAP. In this study nearly $50 \%$ of $S$ pneumoniae cases occurred as coinfections. This finding suggests that the classical presentation of pneumoccocal CAP as the sole pathogen might not be correct and that other pathogens are likely to contribute to the disease. Today the use of more sensitive diagnostic technology is rendering it difficult to make a simple association between agent and illness.

In summary, factors such as age and comorbidities are relevant to the severity of CAP. Despite improvements in identifying an aetiological agent associated with CAP, we were unable to demonstrate a clinical significance during the acute process. The relevant detection of classic, atypical bacteria and viruses should be considered in the initial empirical antimicrobial intervention.

Table 5 Clinical severity according to Fine score and infection classification in 356 adults with community-acquired pneumonia

\begin{tabular}{|c|c|c|c|c|c|c|c|c|c|c|c|c|}
\hline \multirow[b]{2}{*}{ Fine class } & \multicolumn{2}{|c|}{ Total cases } & \multicolumn{2}{|c|}{ Without agent } & \multicolumn{2}{|c|}{ With agent } & \multicolumn{2}{|c|}{ Bacteria } & \multicolumn{2}{|c|}{ Virus } & \multicolumn{2}{|c|}{$\begin{array}{l}\text { Bacteria and } \\
\text { virus }\end{array}$} \\
\hline & $\mathrm{N}$ & $\%$ & $\mathrm{~N}$ & $\%$ & $\mathrm{~N}$ & $\%$ & $\mathrm{~N}$ & $\%$ & $\mathrm{~N}$ & $\%$ & $\mathrm{~N}$ & $\%$ \\
\hline 1 & 84 & 23.6 & 24 & 19.4 & 60 & 25.9 & 38 & 25.0 & 33 & 23.6 & 11 & 18.3 \\
\hline 2 & 74 & 20.8 & 28 & 22.6 & 46 & 19.8 & 25 & 16.4 & 31 & 22.0 & 10 & 16.7 \\
\hline 3 & 69 & 19.4 & 29 & 23.4 & 40 & 17.2 & 27 & 17.8 & 28 & 21.3 & 15 & 25.0 \\
\hline 4 & 87 & 24.4 & 33 & 26.6 & 54 & 23.3 & 39 & 25.7 & 31 & 22.0 & 16 & 26.7 \\
\hline 5 & 42 & 11.8 & 10 & 8.1 & 32 & 13.8 & 23 & 15.1 & 17 & 12.1 & 8 & 13.3 \\
\hline Total & 356 & 100 & 124 & 34.8 & 232 & 65.2 & 152 & 42.7 & 140 & 39.3 & 60 & 16.9 \\
\hline
\end{tabular}


Atypical bacteria were detected in approximately 20\% of cases, justifying antimicrobial coverage. The seasonality of viral respiratory agents should also influence the recommendation for influenza antiviral therapy.

In conclusion:

1. Viruses and atypical bacteria are detected as frequently as $S$ pneumoniae in patients with CAP if modern diagnostic technology is applied.

2. We were unable to demonstrate that either type of infection (bacterial vs viral) or number of pathogens (sole vs coinfections) adversely affected clinical outcome.

3. The detection of multiple infectious agents in adult CAP is common and should be considered in the selection of empirical antimicrobial therapy.

4. Vaccination against influenza and $S$ pneumoniae can reduce adult CAP admission, especially during the winter season.

Acknowledgements The authors thank Ms Angelica Espinoza for helpful assistance in hospital Clinico U de Chile and Letisha Aideyan, Luis Torres and Cristian Moreno for helpful technical assistance.

Funding This work was supported by the Fondo Nacional de Ciencia y Tecnología (FONDECYT) (grant number 1050734); and the Fondo Nacional de Investigación en Salud (FONIS) (grant number SA04 I 2084).

Competing interests None.

Patient consent Obtained.

Ethics approval All cases included completed a duly signed consent form. The study was approved by the Universidad de Chile and Health Services Research and Ethics Committee. Also two National Research Institutions approved the study: FONIS SA04 I 2084 and FONDECYT 1050734.

Provenance and peer review Not commissioned; externally peer reviewed.

\section{REFERENCES}

1 Niederman MS, Mandel LA, Anzueto A, et al. Guidelines for the management of adults with community-acquired pneumonia: diagnosis, assessment of severity, antimicrobial therapy and prevention. Am J Resp Crit Care Med 2001; 163:1730-54

2 Alvarez-Lerma F, Torres A. Severe community-acquired pneumonia. Curr Opin Crit Care 2004;10:369-74.

3 Arnold FW, Summersgill JT, LaJoie AS, et al. A worldwide perspective of atypical pathogens in community-acquired pneumonia. Am J Respir Crit Care Med 2007:175:1086-93.

4 Mandell LA, Wunderink RG, Anzueto A, et al. Infectious Diseases Society of America/American Thoracic Society consensus guidelines on the management of community-acquired pneumonia in adults. Clin Infect Dis 2007;44:S27-72.

5 Barlett JG, Finegold SM. Bacteriology of expectorated sputum with quantitative culture and wash technique compared to transtracheal aspirates. Am Rev Respir Dis 1978:117:1019-27.

6 Forbes BA, Sahn F, Weissfeld AS. Bailey \& Scott's diagnostic microbiology. 12th edn. St Louis, Baltimore: Mosby 2007

7 Larrañaga C, Kajon A, Villagra $\mathrm{E}$, et al. Adenovirus surveillance on children hospitalized for acute lower respiratory infections in Chile (1988-1996). J Med Virol 2000:60:342-6.

8 Avendaño LF, Palomino MA, Larrañaga C. Surveillance for respiratory syncytial virus in infants hospitalized for acute lower respiratory infection in Chile (1989 to 2000). J Clin Microbiol 2003;41:4879-82.

9 Larrañaga C, Martínez J, Palomino MA, et al. Molecular characterization of hospital-acquired adenovirus infantile respiratory infection in Chile using species-specific PCR assays. J Clin Virol 2007;39:175-81.

10 van de Pol A, van Loon AM, Wolfs TF, et al. Increased detection of respiratory syncytial virus, influenza viruses, parainfluenza viruses and adenoviruses with real-time PCR in samples from patients with respiratory symptoms. J Cin Microbiol 2007:45:2260-2.

11 Dowell SF, Anderson LJ, Gary HE, et al. Respiratory syncytial virus is an important cause of community-acquired lower respiratory infection among hospitalized adults. JID 1996;174:456-62.

12 Falsey $A$, Erdman $D$, Anderson $L$, et al. Human metapneumovirus infections in young and elderly adults. JID 2003;187:785-90.

13 Martínez M A, Ruiz M, Zunino E, et al. Detection of Mycoplasma pneumoniae in adult community-acquired pneumonia by PCR and serology. J Med Microbiol 2008:57:1491-95.

14 Martínez MA, Ruiz M, Zunino E, et al. Identification of P1 types and variants of Mycoplasma pneumoniae during an epidemic in Chile. J Med Microbiol 2010;59:925-9

15 Luchsinger $\mathrm{V}$, Ruiz $\mathrm{M}$, Zunino $\mathrm{E}$, et al. Role of neutralizing antibodies in adults with community-acquired pneumonia by respiratory syncytial virus. Clin Infect Dis 2012;54:905-12

16 Fine MJ, Auble TE, Yaely DM, et al. A prediction rule to identify low risk patients with community-acquired pneumonia. N Engl J Med 1997;336:243-50.

17 WHO. Manual for the laboratory diagnosis and virological surveillance of influenza. 2011. ISBN9789241548090. http://www.who.int/influenza/gisrs_laboratory/ manual_diagnosis_surveillance influenza/en/ (accessed 31 Dec 2012).

18 Piedra $P_{1}$ Cron $S$, Jewell $A_{1,}$ et al. Immunogenicity of a new purified fusion protein vaccine to respiratory syncytial virus: a multi- center trial in children with cystic fibrosis. Vaccine 2003;21:2448-60.

19 García D, Hiatt $P$, Jewell $A$, et al. Human metapneumovirus and respiratory syncytial virus infections in older children with cystic fibrosis. Pediatric Pulmonology 2007:42:66-74.

20 Chomczynski P, Sacchi N. The single-step method of RNA isolation by acid guanidinium thiocyanate-phenol-chloroform extraction: twenty-something years on Nat Protoc 2006;1:581-5

21 Cane P, Pringle C. Molecular epidemiology of respiratory syncytial virus: rapid identification of subgroup A lineages. J Virol Methods 1992:40:297-306.

22 Escobar C, Luchsinger V, de Oliveira DB, et al. Genetic variability of human metapneumovirus isolated from Chilean children, 2003-2004. J Med Virol 2009;81:340-4

23 Esper $F$, Weibel $C$, Ferguson D, et al. Evidence of a novel human coronavirus that is associated with respiratory tract disease in infants and young children. J Infect Dis 2005;191:492-8

24 Pitkäranta $A$, Arruda $E$, Maimberg $H$, et al. Detection of rhinovirus in sinus brushings of patients with acute community-acquired sinusitis by reverse transcription- PCR. J Clin Microbiol 1997:35:1791-179.

25 Bartlett JG, Breiman RF, Mandell LA, et al. Community acquired pneumonia in adults: guidelines for management. Clin Infect Dis 1998:26:811-38.

26 Andreo F, Dominguez J, Ruiz J, et al. Impact of rapid urine antigen tests to determine the etiology of community-acquired pneumonia in adults. Respir Med 2006;100:884-91.

27 Murdoch DR. Diagnosis of Legionella Infection. Clin Infect Dis 2003;36:64-9.

28 Jonas D, Rosenbaum A, Weyrich S, et al. Enzyme-linked immunoassay for detection of PCR-amplified DNA of Legionellae in bronchoalveolar fluid. J Clin Microbiol 1995:33:1247-52.

29 Maass M, Bartels C, Kruger S, et al. Endovascular presence of Chlamydia pneumoniae DNA is a generalised phenomenon in atherosclerotic vascular disease. Atherosclerosis 1998;140:S25-30.

30 Martínez MA, Kogan R, Rojas P, et al. Diagnosis of Chlamydia pneumoniae in community acquired pneumonia in children in Chile. Acta Paediatr 2000:89:650-3.

31 Dorigo-Zetsma JW, Verkooyen RP, Van Helden HP, et al. Molecular detection of Mycoplasma pneumoniae in adults with community-acquired pneumonia requiring hospitalization. J Clin Microbiol 2001;39:1184-6.

32 Kogan R, Martínez MA, Rubilar L, et al. Comparative randomized trial of azithromycin versus erythromycin and amoxicillin for treatment of community-acquired pneumonia in children. Pediatr Pulmonol 2003;35:91-8.

33 Lieberman D, Shimoni A, Shemer-Avni Y, et al. Respiratory viruses in adults with community-acquired pneumonia. Chest 2010;138:811-6.

34 Jennings LC, Anderson TP, Beynon KA, et al. Incidence and characteristics of viral community-acquired pneumonia in adults. Thorax 2008;63:42-8. 